\title{
Recent Perspectives on Christianity in the Modern Arab World
}

Laura Robson*

Department of History, Portland State University

\begin{abstract}
Although Christians constitute large and important communities in much of the modern Arab world, scholars have long tended to overlook their histories, viewing them as little more than pawns of Western interests or victims of Muslim overlords. Recently, however, a body of new scholarship has sought to explore the modern experience of Christians in the Arab world. This historiographical article examines the past reluctance to deal with the modern history of Christianity in the Arab world; investigates the reasons for its recent emergence as a topic of interest to historians; analyzes the approaches and contributions of the new scholarship; and suggests some possibilities for future directions.
\end{abstract}

\section{Introduction}

For many decades, scholarship on the modern Arab world largely avoided the topic of Christians. Area studies researchers, who traditionally viewed Islam as central to the coherent definition of the region, were disinclined to investigate the role of Christianity there. Furthermore, the histories of the Arab world's Christian communities raised questions about sectarianism and communal politics which many scholars, both in the West and in the Middle East, were reluctant to approach. Historians responded to these difficulties by presenting Arab Christians as essentially marginal, appearing either as hapless victims of Muslim domination or as agents of the Western powers with which they had religious and political connections. Consequently, the history of Arab Christianity long remained a fringe interest, confined mainly to religious historians working on ecclesiastical history in the context of divinity schools and nearly absent from the secular study of the modern Middle East.

This has changed dramatically in recent years. Scholarship on the Christians of the Arab world has exploded, as evinced by a recent "roundtable" on the subject published in Middle East Studies' flagship journal, by conference presentations at the Middle East Studies Association and the World Congress for Middle East Studies, and by a proliferation of publications in both history and area studies. This sudden upsurge of scholarly interest has emerged alongside increased media coverage of Christian communities in the Middle East - focused especially on the plight of the Christians of Iraq as their nation disintegrated in the aftermath of the American invasion, but also including coverage of the Arab Christian communities of Palestine/Israel, Syria and Egypt. ${ }^{1}$ Such journalistic narratives have tended to emphasize old tropes of Middle Eastern Christians as victims of their Muslim overlords, in need of rescue by the West.

While much of the popular media coverage of Arab Christians has reproduced stereotypes and parroted the least convincing aspects of older accounts, the new scholarly literature has developed the study of Christians in the Middle East in increasingly sophisticated 
ways. This article looks at the past reluctance to deal with the modern history of Arab Christianity, investigates the reasons for its recent emergence as a topic of interest, identifies key trends in the new scholarship, and suggests some possibilities for future directions.

\section{Why So Long Ignored?}

Historically, Christians have constituted important minorities in most of the Arab world, and they still comprise substantial communities throughout the region. The major Christian branches in the Middle East are the Eastern Orthodox churches, which are especially prominent in Syria, Palestine/Israel and Jordan; the Maronite church, based primarily in Lebanon; and the Coptic church, centered in Egypt. Smaller Catholic, Assyrian and Protestant communities are scattered throughout the Levant, Iraq, and North Africa. The Gulf states, especially Bahrain, are also home to small Arab Christian communities, many of whose members are expatriates from other parts of the Arab world. ${ }^{2}$

Precise numbers, though, are often difficult to determine. In Egypt, the Coptic church claims that its adherents make up about $20 \%$ of the population, while official government estimates put the number at about 6\%. Regardless, the Egyptian Coptic church is undoubtedly the largest Arab Christian community in the Middle East; as S. S. Hasan has written, 'even if one accepts the low government estimate of $6 \%$ there is still the fact that the Christian population of Egypt is as large as the Jewish population of the entire state of Israel'. ${ }^{3}$ Numbers are similarly difficult to ascertain for Lebanon. The Christian (mainly Maronite and Greek Orthodox) population probably now represents about 35\% of the Lebanese population, but the lack of census information and the political ramifications of determining communal ratios make such assertions both provisional and controversial. ${ }^{4}$ The Christian population has sunk to historic lows in Palestine/Israel, having dropped from more than $10 \%$ of the Arab population in the first decades of the twentieth century to approximately $2.6 \%$ now. ${ }^{5}$ Arab Christians represent about $6 \%$ of the population in Syria and 3.6\% in Jordan. ${ }^{6}$ North Africa has smaller but still significant Christian communities, with representatives in Libya, Algeria, Tunisia and Morocco. Generally, Christian numbers have declined throughout the region over the last century, as a consequence of high levels of emigration, comparatively low birth rates, and intermarriage with Muslims. ${ }^{7}$

Despite the recent decline in numbers, Arab Christians have historically constituted substantial and important minorities in much of the Arab world. Why, then, has their experience been traditionally overlooked? Above all, historians were long reluctant to highlight religious difference as a tool of analysis for the Middle East, not wishing either to engage a Western view of the region as a hotbed of primitive religious feeling or to fuel a minority local perspective that views religion as the basis for all identity. ${ }^{8}$ As Ottoman historian Bruce Masters has written, 'To place Christians at the center of any research agenda might aid and abet those who would promote the politics of sectarianism in the region by providing unintended fodder for their polemic. As such, even the acknowledgement of the existence of separate religious communities ... has sometimes been deftly sidestepped in the historical literature'. 'Pressure on Middle Eastern historians to emphasize themes of national or regional loyalty over religious identity has exacerbated the problem, producing histories that simply do not acknowledge the existence of Christian communities as distinct groups within the nation. ${ }^{10}$ Ironically, as Ussama Makdisi has pointed out, this silence surrounding issues of communal and especially minority identities has 'allow[ed] the void to be filled with scholarship obsessed with the idea of perpetual 
hostility between Christian and Muslim minorities and an oppressive monolithic Muslim majority ${ }^{11}$ - a common perspective in the admittedly limited older literature dealing with the histories of the Arab Christian communities. ${ }^{12}$

A suspicion of Christianity's historical associations with various forms of Western imperialism also contributed to the dearth of scholarship on the Arab Christian experience. The secular scholarly community was long accustomed to considering Christianity primarily within the context of the history of European imperialism and, later, American cultural, military and economic domination. Historians of the Middle East, animated by discussions of the frequently exploitative attitude of the West towards the Arab world, were not moved to study a religion they associated primarily with Western imperial expansionism. Arab Christian contacts with Western church institutions, and the ways in which some of the Western powers had claimed Eastern Christian communities as 'protectorates' during the nineteenth and early twentieth centuries, further helped cement the assumption that Arab Christianity was more an outpost of Western imperial interests than an authentically Middle Eastern entity worthy of close study. The explicitly anti-Islamic agenda of many of the most vocal contemporary political expressions of Christianity in the West probably also served to further this reluctance to explore the Middle Eastern Christian experience. (In the Middle East itself, it has also advanced the sense of a radical disconnect between Arab Christians and what they see as their inexplicably hostile Western coreligionists - a sense of estrangement deepened by the rise of evangelical Christian Zionism. $)^{13}$

The small body of older scholarship on Christian communities in the Middle East came mainly out of ecclesiastical institutions not regarded as mainstream by many historians. ${ }^{14}$ Much of it assumed a theological rather than a historical perspective, and tended to understand modern Arab Christianity as conditioned primarily by a long pre-modern experience of religious resistance to Islam. ${ }^{15}$ Some of this work explicitly celebrated the Christian presence in the Middle East, and especially in Palestine, as a praiseworthy holdout of Christian tradition against a hostile and constantly threatening Muslim presence, and viewed the communities' dwindling numbers as a threat to Christian tradition. 'If it should happen', religious historian Robert Wilken wrote, 'that the only Christians to survive in the Holy Land were caretakers of the holy places, Christianity would forfeit a precious part of its inheritance... Only people, not stones and earth and marble, can bear an authentic witness'. ${ }^{16}$ Accounts like this have served to distance the study of Middle Eastern Christianity from contemporary secular scholarship. ${ }^{17}$

An incapacity on the part of historians of the Middle East to engage with the specifics of Eastern Christianity has further limited the study of Arab Christian history. For most historians of the modern Arab world, the functioning of the Orthodox and other eastern churches that dominate Arab Christianity remains an arcane mystery. Its theology, ecclesiastical structure, and institutional history are unfamiliar to many scholars trained in universities in Europe and the United States, where Eastern Christianity is not a commonly taught subject and where the structures of area studies throw up barriers between the Middle East and Eastern Europe.

Moreover, there continue to be substantial practical difficulties with research on the institutions of eastern Christianity. Throughout the Middle East, gaining access to patriarchal and official church archives is nearly always difficult and often impossible. To add to the practical problems of researching Arab Christian church history, the relevant documents that are available to scholars - such as official church histories or hagiographies-have often been regarded as literary rather than historical, and therefore unsuitable for use in secular historical inquiry. ${ }^{18}$ Partly as a consequence of these logistical and 
practical impediments, there have been relatively few serious attempts to grapple with the roles of the eastern churches in the modern Middle East. ${ }^{19}$

Even in the context of global Christian studies, which in recent years has generated a great deal of innovative scholarship on Christianity in Africa, Latin America, and South and Southeast Asia, Arab Christians have been largely ignored. The field focuses primarily on Christian communities spawned by Western Protestant and Catholic mission efforts: their alignments with colonial and postcolonial forms of rule, their strategies of resistance and accommodation towards the West, and their incorporation of local traditions into mission-taught Christian dogmas. ${ }^{20}$ Despite the global orientation of these scholars, their underlying assumption is that Christianity has Western roots. The histories of the various Arab Christian communities, who are mainly not converts and who profess an indigenous, non-Western form of Christianity, do not fit easily within this paradigm.

Finally, of course, there is the broad assumption that Islam is a-perhaps the-primary unifying factor justifying the area study of the Middle East. The presence of substantial Arab Christian populations in the Middle East challenges the belief that the Middle East is a reasonably homogenous Muslim region that can usefully be placed in opposition to a predominantly Christian West. Further, area study has argued for the essential separation of the Middle East and eastern Europe, leaving little room to discuss the long history of exchange and encounter between the two 'areas' or to recognize the porous nature of the cultural, political, economic and linguistic demarcations that separate them. Arab Christians' long history of engagement with eastern Europe and Russia points up the arbitrary nature of the borders that area studies departments have erected around the Middle East. The modern history of Arab Christianity complicates the assumption that the Middle East constitutes a natural or even a viable category of analysis, and may suggest certain weaknesses in the way area study has conceptualized the Middle East as a region.

\section{Why Now? The Recent Upsurge}

Recent interest in the Christians of the Arab world has been in part a response to the rise of political Islam since the 1970s and the consequent Islamization of Middle Eastern politics and public discourse. This phenomenon affected Arab Christians in two main ways. First, as religion became a more prominent aspect of Middle Eastern political life, the relationship between religious minorities and the state grew more fraught in a number of Middle Eastern nations. The position of the Coptic community in Egypt represents a particularly clear example; as an opposition committed in varying degrees to political Islam has placed pressure on a theoretically secular government to Islamize aspects of Egyptian political life, the Coptic position appears to have become more precarious. ${ }^{21}$ Second, as Islam's institutional appeal rose in the wake of the many failures of Middle Eastern secular nationalism, Christians similarly recommitted to Christianity as an institutionally and politically significant entity, especially in Egypt and Lebanon. ${ }^{22}$ The rise of political Islam therefore assisted the rise of new brands of political Christianity throughout the Arab world, and brought new attention to the issues surrounding Arab Christianity.

Further, as the question of sectarianism emerged as a major debate in Middle Eastern history, the experience of religious minorities came to seem especially relevant. Sectarianism, always a matter of interest to scholars of the region, became a central concern in Middle Eastern history in the early 1990s, when Samuel Huntington and Bernard Lewis began to publish their 'clash of civilizations' theories that asserted the basic incompatibility 
of Islam and modernity and presented religion as the basis for all identity in the Middle East. $^{23}$ Scholars opposing this point of view began to approach sectarianism as a historically specific process dictated by the particular conditions of modernity, rather than a permanent, essential, natural aspect of politics in the Islamic world. ${ }^{24}$ Their investigations into the meaning of sectarianism and the historical origins of sectarian politics in the Middle East have necessarily required a closer examination of religious minorities and have encouraged the development of a scholarly literature on the region's Christians.

Arab Christians themselves have participated in raising the profiles of their communities, asserting their full membership and participation in the history and politics of the region and demanding that attention be paid to their historical experiences. Palestinian Christians have been especially central to this effort; in recent decades, a number of publications have come out of Palestine from Palestinian Christian writers that discuss in frank terms issues of identity, belonging, participation in the Palestinian nationalist movement, and role in the Palestine-Israel conflict. ${ }^{25}$ Such writings include voices from the diaspora as well as the Arab world; they have drawn attention to the Palestinian Christian experience and raised interest, both scholarly and popular, in the narrative of Arab Christianity in the modern Middle East.

A recent broader interest in the study of global Christian missions has also helped bring the history of Middle Eastern Christianity to greater prominence. Long considered the preserve of scholars in ecclesiastical institutions, the history of missions has now emerged as a mainstream topic. Rejecting earlier assumptions that missions served as little more than the cultural arm of imperialism, scholars of regions as disparate as North America, Africa, and India have begun to pay serious attention to the interactions of global Christian mission efforts with local populations and the consequences of such encounters. ${ }^{26}$ In the context of the Middle East, this has brought a great deal more attention to the Arab Christian populations who were the primary targets and contacts of Western missions operating in the Arab world from the mid-nineteenth century onwards.

Finally, the 'global turn' which has influenced the discipline of history broadly over the past two decades has increased interest in the Christian communities of the Middle East. The modern history of the Arab Christians is essentially transnational; as well as the multiplicity of class, ethnic, national and regional loyalties common to both Christians and Muslims in the Middle East, it has involved supra-national institutions like the Greek Orthodox patriarchate and the Vatican; Orthodox ties with co-religionists in Eastern Europe and Russia; Catholic ties with France and Italy; contact with Western missionaries from Britain, Germany, France and the United States; and enormous networks of expatriate Christian families and churches in the diaspora. The global turn has meant that rather than viewing Arab Christianity as little more than an outpost of Western interests in the Middle East, scholars interested in new kinds of transnational narratives have been eager to explore its genuinely global nature.

\section{New Trends}

Above all, recent scholarship on Arab Christians in the modern Middle East attempts to deal sensitively with the meaning of religious practice and community belonging, without assuming an absolute and unchanging meaning for religious affiliation in the Arab world. As Anna Akasoy has recently noted in a different context, 'Even though we may be able to tell whether someone was a Christian or Muslim, we may not understand what that meant for him or her'. ${ }^{27}$ Such an approach constitutes a reaction to much of the older scholarship on Arab Christianity, which often assumed belief in the Christian doctrines 
for all members of the community and took for granted a permanent and unbridgeable divide between Christians and Muslims. Instead of making such sweeping assumptions, more recent approaches focus on specific expressions of religious practice by individuals, families and church leaders. Geraldine Chatelard, for instance, in her research on the Arab Christians of Madaba, Jordan, investigates the ways in which local Christians who also identify as Bedouins share cultural and religious practices with Muslim Bedouins. ${ }^{28}$ Gender provides an important analytical framework in some of this new work. Febe Armanios describes how the Coptic clergy in Egypt set out newly specific ideas about female virtue and female sexuality that owed as much to secular political ideologies circulating in the post-Nasser period as to longer-standing church traditions. ${ }^{29}$ Similarly, Nelly van Doorn-Harder's work focuses on the particulars of daily religious practice and community activity among different Egyptian Coptic communities, including Coptic nuns. ${ }^{30}$ Akram Khater's forthcoming book offers this kind of gendered specificity by focusing on the remarkable experience of a single person, a Catholic nun and charismatic in eighteenth-century Lebanon. ${ }^{31}$ Such investigations break down assumptions that Arab Christian communities were, as Bernard Heyberger has put it, 'immutably coherent and homogenous', unaffected by changing conditions and isolated from their Muslim compatriots. ${ }^{2}$ Instead, they focus on the ways in which Arab Christians have forged their communal identities and practices through constant and active engagement with their local, regional and national communities - an important re-integration of Arab Christian narratives into the broader history of the region, and a reminder of the heterogeneity of the Arab Christian historical experience.

Other recent work has investigated how the category of 'Christian' has overlapped with regional, ethnic and, especially, class identifications, arguing that communal affiliation was just one of a number of simultaneously held identities. Not all this work focuses explicitly on the Christian populations of the Arab world. Keith Watenpaugh, for instance, does not offer extensive analyses of religious identification in his book Becoming Modern in the Middle East; nevertheless, he makes an important contribution to the field by examining how the Christian-dominated Syrian middle classes in late nineteenth and early twentieth century Aleppo viewed themselves as avatars of a specifically Arab modernity. ${ }^{33}$ Vivian Ibrahim's work on the Copts in the mid-twentieth century suggests a number of alternate identifications and loyalties that sometimes led to intra-communal tensions. ${ }^{34}$ Paul Sedra has also argued for a more nuanced approach to subaltern and elite Coptic histories. ${ }^{35}$ Many Arab Christians themselves have focused on this question of identification, objecting in the strongest terms to being labeled a 'minority', declaring their primary loyalties to be ethnic or national rather than religious, and proclaiming the authentically Arab and Middle Eastern nature of their historical experience.

Such accounts seek to complicate long-held assumptions that religious categories, and perhaps especially minority religious categories, trumped all other forms of identity in the modern Arab world and inevitably meant a rigid communal segregation. Some of them have also suggested that the sectarian divisions now evident in parts of the contemporary Middle East are not the results of long-standing communal hostilities but of an aggressive British and French colonial occupation that categorized subjects by religion for its own purposes. Laura Robson's recent work has examined British efforts in mandate Palestine to construct religion as a legal and political category in specifically colonial ways; similarly, Benjamin White has made the case that the French mandate state in Syria deliberately promoted the concept of 'minority' identities. ${ }^{36}$ Kais Firro argues that the persistence of these European-drawn national borders and religious divisions into the postcolonial period created permanent difficulties for Christians, who were often forced 
to declare their allegiance to a nationalist vision associated with elites and positioned against a much more populist Islamist discourse. ${ }^{37}$

Newer scholarship also rejects the longstanding narrative of Arab Christian victimhood and marginalization, a trope that recent journalistic accounts depicting Middle Eastern Christianity as in an irreversible state of decline have further perpetuated. As Paul Rowe has written, the 'widespread concern today that Christians are in declining numbers in the Middle East easily falls prey to the enervating assertion that they are victims of persecution or mere relics of a fading past and runs the risk of once again robbing Christians of agency as powerful actors in their own societies' ${ }^{38}$ A number of recent historical accounts have explicitly positioned themselves as rehabilitating Arab Christians as agents of their communities' destinies, and as authentic and essential parts of Arab historical, cultural, and political narratives. S. S. Hasan, for instance, describes the recent history of Egypt's Coptic community as a move 'from a mere ethnic category to a solidari community', adding that this regrouping was 'a deliberate, creative enterprise, not merely a defensive reaction'. 39 Similarly, Alexander Henley has recently argued that the Maronite patriarchate's abstention from national political debate during the Lebanese civil war was not a reflection of the decline of the power of the Maronite community, but an indication of shifting alignments and political loyalties within the church community itself. ${ }^{40}$ Such work rejects the idea of the inevitable decline of the Middle East's Christians, instead examining them as vibrant communities committed to active and creative participation in regional, national, and local politics.

A considerable amount of the recent work on Arab Christians has focused on their relationship with Western missions. Rather than assuming an imperial relationship between Western missionaries and the Eastern Christians who were their targets, it looks at specific local impacts, focusing especially on the joint development of educational institutions, a secularizing and liberalizing public discourse, and global Christian networks. Rejecting the old trope that Arab Christians, under the influence of Western missionaries, were responsible for bringing 'modernity' into Arab political thought, ${ }^{41}$ newer work nevertheless insists that the contact between European and American missions and indigenous Arab Christian populations had an important role in creating new kinds of transnational awareness and public discourse in the Middle East from the mid-nineteenth century on. Ussama Makdisi, in his Artillery of Heaven, tells the story of a young Maronite, converted to Protestantism by American missionaries and eventually martyred for his newly acquired beliefs, who later became the subject of a book by the famous Maronite-turned-Protestant intellectual Butrus al-Bustani. In this case, the Protestant-Arab Christian mission encounter contributed to al-Bustani's articulation of a 'seminal plea for the practice of liberalism that was neither derived from, nor fully independent of, the context of mission and empire'-a conception of new kinds of political community, involving the explicit recognition of Muslims and Christians as political equals. ${ }^{42}$ Similar arguments occur in Heather Sharkey's American Evangelicals in Egypt, in which she makes the case that actual conversions were the least important legacy of the American Protestant mission encounter with the Coptic church in Egypt: 'the counting of baptisms and bodies in churches cannot alone measure the impact of an encounter that elicited striking cultural 'conversions' or transformations among Egyptians, Americans and others'. ${ }^{43}$ The missionary presence in Egypt during the nineteenth and twentieth century, Sharkey argues, led to a refocusing within the Coptic church on lay worship; expanded educational opportunities in Egypt for Muslims and Christians alike, and especially for women; the development of new forms of social organization, particularly the youth groups that would come to play such an important political role in twentieth-century Egyptian politics; and, not least, major 
changes in communal relations, as missionaries simultaneously associated themselves with the Coptic churches and with institutions of British and American colonial power, thereby instilling a suspicion of Egyptian Christians among the Muslim population that persists today. ${ }^{44}$ Paul Sedra deals with some of the same themes, arguing that missions aimed above all at a cultural conversion to the Western doctrine of 'industry, discipline and order'. ${ }^{45}$ Taking gender into account, Ellen Fleischmann has examined how the Syrian-American mission encounter shaped gender norms among the mainly Christian, middle-class Syrian women with whom the missions had the most contact, but only as 'one of many interdependent, linking factors' ${ }^{46}$ This new body of work shows how the active encounters between Arab Christians and Western missionaries in Egypt and the Levant helped reshape concepts of communalism, education, social organization and political reform, with important consequences for both Christians and Muslims.

Contemporary historical scholarship, then, seeks to re-integrate the study of Arab Christianity into the historiography of the modern Middle East. These recent historical narratives have tried to demonstrate the 'authenticity' of the Arab Christian experience, placing it beside Islam as a central aspect of the region's history and asserting its essentially Arab and Middle Eastern (rather than Western and imperialist) character. Simultaneously, scholars have begun to view the Arab Christian experience as a demonstration of the inherently global nature of modern Middle Eastern history, citing Arab Christians' connections to the West through mission contacts and shared educational networks, to Eastern Europe through the institutions of Eastern Orthodox Christianity, and to Arab Christian diasporas throughout the world. This globalizing religious outlook often coexisted quite comfortably with local, regional, ethnic and national loyalties; this recent scholarship argues strongly that Arab Christian communities actively engaged with their Muslim compatriots in attempts to build not only viable independent political structures but also vibrant social and cultural institutions throughout the Middle East. Above all, then, new scholarship has sought to challenge the idea that Arab Christians constituted segregated and victimized communities in the nineteenth and twentieth century Middle East.

\section{Some Thoughts on Future Directions}

The recent spate of historical scholarship on the Arab Christians of the Middle East has been a welcome and salutary addition to the field. It emphasizes the heterogeneity of the region and encourages a more global and transnational approach, as well as telling a number of long-ignored stories. It also offers challenges to some of the more intractable stereotypes of the Middle East: the oft-repeated 'clash of civilizations' theory, the belief that the region is dominated by a 'primitive' and fundamentalist Islam, and the notion of an inherent, unwavering and violent sectarianism characterizing Middle Eastern politics are all undermined by what recent scholarship has had to say about the Arab Christian historical experience. Clearly, this is a new subfield that has a great deal to contribute to broader histories of the Middle East. How might it continue to develop?

The scholarship's focus on defending a claim of authenticity for the Arab Christian experience is entirely understandable, given the long historiographical tradition of positioning Arab Christians as outsiders excluded from their majority-Muslim societies and as victims of Islam and pawns of Western interests. It may be time, however, to move away from this trope. The framework of defending the cultural authenticity of Arab Christians suggests, first, the existence of a recognizably 'authentic' Middle Eastern cultural experience; attempts to expand the definition beyond Islam do not alter the essentialist nature 
of this argument. Subjects should not need to pass a kind of litmus test of cultural belonging in order to be declared worthy of intellectual attention, and insistence on the 'authenticity' of the Arab Christian experience within the context of the Middle East has meant that it has been easier for scholars to bring attention to the Arabic-speaking Christians of Lebanon, Palestine, Egypt and Syria than the non-Arabic-speaking churches in the Arab world, such as the Armenians of Jerusalem or the Chaldean Christians of Iraq, who speak the Syriac dialect Sourath. ${ }^{47}$ An acceptance of the genuinely transnational and transethnic nature of Middle Eastern Christianity (and indeed of the Middle East more generally) will allow scholars to move beyond the strictures of area and ethnic studies, as well as nationalist historiographies, to address a number of still-neglected narratives.

Studies of Arab Christianity have until now been largely atomized by nation and denomination; it may be useful in the future to consider a broader and perhaps a more explicitly comparative approach. There are important comparisons to be made among the many varieties of Christian experience throughout the Middle East, as well as studies of the networks that connect, for instance, Greek Orthodox communities in Palestine, Lebanon and Syria, or Maronite communities in Lebanon with coreligionists in Syria and Israel. Comparative attention to the histories of Christians or other religious minorities in non-Middle Eastern Muslim contexts-for instance, placing Christian-Muslim relations in Indonesia, Hindu-Muslim relations in South Asia, or Christian histories in Ethiopia alongside the Arab Christian experience in the Middle East-would likely also yield important insights. ${ }^{48}$ Similarly, scholars might consider giving more serious treatment to the linkages between Arab Christians and Eastern Europe. The history of the late nineteenth century uprisings against the Greek Orthodox hierarchy in the Balkans, for instance, spread into Antioch, Alexandria and Jerusalem, where Arab congregants followed their Balkan coreligionists' examples and demanded control over church finances, services and scriptures in the local vernacular, and appointments in the higher levels of the church hierarchies. Careful examination of such historical connections might open up new avenues of exploration for the study of nationalism, ethnic identification, and the construction of self-consciously modern political structures in the nineteenth and twentieth century Middle East.

Finally, scholars have as of yet given relatively little attention to the histories of Middle Eastern Christians in the diaspora, a demographic whose experiences raise fascinating questions about the role of religious identity in transnational as well as local and regional alignments. What might it mean, for instance, for a Christian Jordanian family, belonging to a religious minority but an ethnic and linguistic majority, to become part of an Arab ethnic minority but join the Christian religious majority as newly minted citizens of Australia? A few studies of the Coptic diaspora have demonstrated how rich an area of study this might be, ${ }^{49}$ and it seems likely that scholars will expand their investigations into this area in the coming years.

The recent scholarly interest in the Middle East's Christian communities has expanded the historiography of the modern Middle East in a number of valuable ways. It has encouraged scholars and students to think of the region as a globally connected, heterogeneous, complex place, and has fueled the rejection of common notions of the Middle East as an isolated region that speaks primarily with the voice of Islamic fundamentalism. It has brought attention to the historical specifics of identity construction-local, national and regional-in the Arab world and offered insights into the relations between religion and politics in Ottoman, colonial and post-colonial contexts. It is to be hoped that scholars will continue to develop a historiography of Arab Christianity that illuminates the ineluctably global, multifarious, and multivocal character of the modern Middle East. 


\title{
Short Biography
}

Laura Robson is currently Assistant Professor in the Department of History at Portland State University in Portland, Oregon. She holds a doctorate in history from Yale University, and has been the recipient of a number of fellowships and grants from such bodies as the Andrew Mellon Foundation, the American Council of Learned Societies, and the Whiting Foundation. Her book Colonialism and Christianity in Mandate Palestine will appear from the University of Texas Press in 2011.

\author{
Notes \\ * Correspondence: Department of History, Portland State University, PO Box 751, Portland, OR 97207-0751, \\ USA. Email: 1robson@pdx.edu.
}

1 See, for instance, 'Violence in Mosul Forces Iraqi Christians to Flee', New York Times, 10 Oct, 2008; 'Iraqi Christians' long history', BBC News, 13 Mar, 2008, http://news.bbc.co.uk/2/hi/3526386.stm; 'Iraqi Christians under fire', Daily Telegraph, 3 Apr, 2010; 'Egyptian Christians Clash with Police', New York Times, 7 Jan, 2010; 'The Forgotten Faithful', National Geographic Jun 2009; 'Palestinian Christians look back on a year of troubles', New York Times 11 Mar 2007; 'Sectarian violence, economic hardship accelerate exodus of Bethlehem's Christians', Chicago Tribune, 21 Dec, 2006.

2 For a useful overview of Christian demographics in the Gulf, see F. Strickert, 'Christianity in the Gulf, Washington Report on Middle East Affairs (March 2000): 68-71.

3 S. S. Hasan, Christians versus Muslims in Modern Egypt: The Century-Long Struggle for Coptic Equality (Oxford: Oxford University Press, 2003), 18; see also P. Makari, Conflict and Cooperation: Christian-Muslim Relations in Contemporary Egypt (Syracuse: Syracuse University Press, 2007), 38-9.

4 On the problems of the last census, conducted in 1932, and the political difficulties of census-taking in Lebanon, see especially R. Maktabi, 'The Lebanese Census of 1932 Revisited: Who Are the Lebanese?' British Journal of Middle East Studies, 26/2 (1999): 219-41.

5 For Palestine, see B. Sabella, 'The Emigration of Christian Arabs: Dimensions and Causes of the Phenomenon', in A. Pacini (ed.), Christian Communities in the Arab Middle East: The Challenge of the Future (Oxford: Clarendon Press, 1998), 127-54, and 'Palestinian Christian Emigration from the Holy Land', Proche-Orient Chretien, 41 (1991): 74-85.

6 P. Fargues, 'Demographic Islamization: Non-Muslims in Muslim Countries', SAIS Review, 21/2 (2001): 103-16.

7 On this point, see especially Fargues, 'Demographic Islamization'.

8 As Sami Zubaida has observed, the focus on religion as a primary mover in the Middle East has been upheld in entirely different ways: 'For religious and political Muslims, it is held with pride, as a steadfast attachment to God and his revelations, valid for all times. For Western commentators, it is part of Muslim (and Arab) exceptionalism-impervious to the march of modernity and progress'. See 'Islam and Secularization', Asian Journal of Social Science, 33/3 (2005): 438.

9 See B. Masters, Christians and Jews in the Ottoman Arab World: the Roots of Sectarianism (Cambridge: Cambridge University Press, 2001), 4. This state of affairs, he also notes, is in sharp contrast to a plethora of historical writings on the position of Jewish communities in the Middle East which have appeared since the founding of the state of Israel.

10 U. Makdisi, Artillery of Heaven: American Missionaries and the Failed Conversion of the Middle East (Ithaca: Cornell University Press, 2008), 8.

11 U. Makdisi, Artillery of Heaven, 8.

12 A particularly egregious example is B. Ye'or, The Dhimmi: Jews and Christians under Islam (Rutherford, NJ: Fairleigh Dickinson University Press, 1985), and The Decline of Eastern Christianity under Islam: From Jihad to Dhimmitude (Madison, NJ: Fairleigh Dickinson University Press, 1996). For examples of less aggressive interpretations that nevertheless assume a degree of victimhood, see R. Haddad, Syrian Christians in Muslim Society: An Interpretation (Princeton: Princeton University Press, 1970), and R. B. Betts, Christians in the Arab East: A Political Study (Athens: Lycabettus Press, 1975).

13 Some of these issues have also been raised in the context of anthropological scholarship on Christianity broadly. For a useful overview, see F. Cannell's introduction to The Anthropology of Christianity, ed. F. Cannell (Durham: Duke University Press, 2006), 1-50.

${ }^{14} \mathrm{P}$. Rowe, B. Heyberger and F. McCallum all comment on this positioning of the topic in their contributions to 'Roundtable: How Does New Scholarship on Christians and Christianity in the Middle East Shape How We View the History of the Region and its Current Issues?' International Journal of Middle East Studies, 42/3 (2010): 471-88.

15 See, for instance, K. Cragg, The Arab Christian: A History in the Middle East (London: Mowbray, 1992), on the problem of Israel: 'All these burdens of mind and spirit devolve most acutely of all on Arab Christians. It is urgent 
for outsiders to reckon perceptively with the contradiction between spiritual ancestor and political enemy under which Christians suffer in the Middle East. For Israel is both' (240).

${ }^{16}$ R. L. Wilken, The Land Called Holy: Palestine in Christian History and Thought (New Haven: Yale University Press, 1992), 254.

17 However, it should be noted that this type of religious history has offered a venue for both Western and Middle Eastern scholars to point out the long history of cultural accommodation and mutual influence between Muslims and Christians in the region-an important issue with which most Middle Eastern historians, intent on rejecting what they see as a Western-centric focus on Christianity, have been reluctant to engage. See, for instance, the essays in A. O'Mahony et al. (eds.), The Christian Heritage in the Holy Land (London: Scorpion Cavendish, 1995).

18 On ways of using such sources for historical purposes, see M. Shenoda, 'Displacing Dhimmi, Maintaining Hope: Unthinkable Coptic Representations of Fatimid Egypt', International Journal of Middle East Studies, 39/4 (2007): 587606. I thank the anonymous reviewer who made this important point to me.

19 This is another space where most of the few extant contributions come from a descriptive, ecclesiastical approach rather than a disciplinary area. See, for instance, S. Roussos' articles on the Greek Orthodox patriarchate. A notable recent exception is F. McCallum, 'The Political Role of the Patriarch in the Contemporary Middle East', Middle Eastern Studies, 43/6 (2007): 923-40.

${ }^{20}$ Some good examples of this type of global Christian studies are P. Jenkins, The Next Christendom: The Coming of Global Christianity (Oxford: Oxford University Press, 2002); A. Walls, The Missionary Movement in Christian History: Studies in the Transmission of Faith (Maryknoll, New York: Orbis, 1996); and L. Sanneh, Disciples of All Nations: Pillars of World Christianity (Oxford: Oxford University Press, 2008).

${ }^{21}$ On this point, see especially P. Rowe, 'The Challenge of Political Islam: Non-Muslims and the Egyptian State', Middle East Journal, 64/4 (2010): 654-5, and M. Tadros, 'Vicissitudes in the Entente between the Coptic Orthodox Church and the State in Egypt (1952-2007)', International Journal of Middle East Studies, 41/2 (2009): 269-87.

${ }^{22}$ See, for instance, E. Hagopian, 'Maronite Hegemony to Maronite Militancy: The Creation and Disintegration of Lebanon', Third World Quarterly 11/4 (1989): 101-17; S. Haddad, 'A Survey of Maronite Christian Socio-Political Attitudes in Postwar Lebanon', Islam and Christian-Muslim Relations, 12/4 (2001): 465-80; and especially the many relevant articles in M. Shatzmiller (ed.), Nationalism and Minority Identities in Islamic Societies (Montreal: McGill-Queen's University Press, 2005).

${ }^{23}$ B. Lewis coined the term 'clash of civilizations' in his much-read article 'The Roots of Muslim Rage', The Atlantic Monthly, 266/3 (September 1990): 47-60; he expands on this premise in some of his other work, including What Went Wrong? The Clash between Islam and Modernity in the Middle East (New York: Oxford University Press, 2002). See also S. Huntington's famous exposition on the theme in 'The Clash of Civilizations?' Foreign Affairs, 72/3 (1993): 22-49, and The Clash of Civilizations and the Remaking of World Order (New York: Simon \& Schuster, 1996).

${ }^{24}$ For a useful overview of recent scholarly approaches to the question of sectarianism in the Middle East, see the group of short articles by U. Makdisi, E. Davis, J. Peteet and S. Joseph on the question, 'How Useful has the Concept of Sectarianism been for Understanding the History, Society and Politics of the Middle East?' International Journal of Middle East Studies, 40/4 (2008): 550-60.

${ }^{25}$ See, for instance, N. K. Farah, A Continent Called Palestine: One Woman's Story (London: SPCK, 1996); R. A. El-Assal, Caught in Between: The Story of an Arab Palestinian Christian Israeli (London: SPCK, 1999); M. Raheb, I Am a Palestinian Christian (Minneapolis: Fortress Press, 1995); and the many works of N. Ateek, including Faith and the Intifada: Palestinian Christian Voices (Maryknoll, NY: Orbis, 1992), and Justice, and Only Justice: A Palestinian Theology of Liberation (Maryknoll, NY: Orbis, 1989). For an overview of some of the Palestinian Christian theological approaches to the Arab-Israeli conflict and the particular position of Arab Christians in Palestine/Israel, see L. Robson, 'Palestinian Liberation Theology, Muslim-Christian Relations and the Arab-Israeli Conflict', Islam and Christian-Muslim Relations, 21/1 (2010): 39-50.

${ }^{26}$ Historians of India, Africa and Asia have all dealt extensively with Christianity in these colonial and post-colonial contexts. See, for instance, G. Visawanathan, Outside the Fold: Conversion, Modernity, and Belief (Princeton University Press, 1998); J. and J. Comaroff, Of Revelation and Revolution, 2 vols. (Chicago: University of Chicago Press, 1991 and 1997); L. Sanneh, The Changing Face of Christianity: Africa, the West, and the World (Oxford: Oxford University Press, 2005); and B. Cooper, Evangelical Christians in the Muslim Sahel (Bloomington: Indiana University Press, 2006). On the relationship between missions and the European imperial project, see especially A. Porter, Religion Versus Empire? British Protestant Missionaries and Overseas Expansion, 1700-1914 (Manchester: Manchester University Press, 2004).

27 A. Akavoy, 'Convicencia and its Discontents', International Journal of Middle East Studies, 42/3 (August 2010): 493.

${ }^{28}$ G. Chatelard, Briser la mosaique: Lien social et identities collective chez les chretiens de Madaba, Jordanie, 1870-1997 (Paris: Editions du CNRS, 2004).

${ }^{29}$ F. Armanios, "The "Virtuous Woman": Images of Gender in Modern Coptic Society', Middle Eastern Studies, 38/1 (2002): 110-30.

${ }^{30}$ See especially N. van Doorn-Harder, Contemporary Coptic Nuns (Columbia: University of South Carolina Press, 1995); 'Finding a Platform: Studying the Copts in the 19th and 20th Centuries', International Journal of Middle East 
Studies, 42/3 (2010): 479-82, and with K. Vogt (eds.), Between Desert and City: The Coptic Orthodox Church Today (Oslo: Novus Verlag, 1997).

31 A. Khater, Embracing the Divine: Passion, Politics and Gender in the Christian Middle East, 1720-1798 (Syracuse: Syracuse University Press, 2011).

32 B. Heyberger, 'Eastern Christians, Islam and the West: A Connected History', International Journal of Middle East Studies, 42/3 (2010): 475.

33 K. Watenpaugh, Becoming Modern in the Middle East (Princeton: Princeton University Press, 2006).

34 V. Ibrahim, The Copts of Egypt: The Challenges of Modernisation and Identity (London: Tauris, 2010). Another work to deal with some of the same issues is B. Voile, Les Coptes d'Egypte Sous Nasser: Saintete, Miracles, Apparitions (Paris: CNRS, 2004).

35 P. Sedra, 'Writing the History of the Modern Copts: From Victims and Symbols to Actors', History Compass 7/3 (2009): 1049-63.

36 L. Robson, Colonialism and Christianity in Mandate Palestine (Austin: University of Texas Press, 2011), and B. White, 'The Nation-State Form and the Emergence of "Minorities”' in French Mandate Syria, 1919-1939', Ph.D. diss. (Oxford University, 2008); see also N. Haiduc-Dale, 'Nationalism and Religious Identification: Palestinian Christians in Mandate Palestine, 1918-1948', Ph.D. diss. (New York University, 2009).

37 K. Firro, Metamorphosis of the Nation (al-Umma): The Rise of Arabism and Minorities in Syria and Lebanon, 18501940 (Brighton: Sussex Academic Press, 2009), 148-9.

38 P. Rowe, 'The Middle Eastern Christian as Agent', International Journal of Middle East Studies, $42 / 3$ (2010): 473.

39 Although, as others have pointed out, she also emphasizes the centrality of sectarian tensions to the modern Coptic experience. See S. S. Hasan, Christians versus Muslims in Modern Egypt: The Century-Long Struggle for Coptic Equality (Oxford: Oxford University Press, 2003), 258-9.

40 A. Henley, 'Politics of a Church at War: Maronite Catholicism in the Lebanese Civil War', Mediterranean Politics, 13/3 (2008): 353-69.

41 As was first argued by G. Antonius, The Arab Awakening: The Story of the Arab National Movement (London: Hamilton, 1938), and was put forward in a slightly different form by A. Hourani, Arabic Thought in the Liberal Age, 1798-1939 (London: Oxford University Press, 1962), among others.

42 U. Makdisi, Artillery of Heaven, 213.

43 H. Sharkey, American Evangelicals in Egypt: Missionary Encounters in an Age of Empire (Princeton: Princeton University Press, 2008), 218.

44 Ibid., Princeton University Press, 1-17.

45 P. Sedra, 'John Lieder and his Mission in Egypt: The Evangelical Ethos at Work among Nineteenth-Century Copts', Journal of Religious History, 28/3 (2004): 222. Sedra argues that this brand of mission activity was explicitly colonial in nature. In his subsequent essay 'Missionaries, Peasants, and the Protection Problem: Negotiating Coptic Reform in Nineteenth-Century Egypt', in A. Amanat and M. T. Bernhardsson (eds.), U.S. - Middle East Historical Encounters: A Critical Study (Gainesville: University of Florida Press, 2007), 77-100, Sedra looks at the reaction of the Copts at whom this mission activity was directed and describes how they too were 'parties to a cultural negotiation... in which modernity was manipulated, and tradition, invented' (96).

46 E. Fleischmann, 'Impact of American Protestant Missions in Lebanon on the Construction of Female Identity', Islam and Christian-Muslim Relations, 13/4 (2002): 422.

47 For a rare examination of the Chaldean Christians of Iraq, see A. O'Mahony, 'The Chaldean Catholic Church: The Politics of Church-State Relations in Modern Iraq', Heythrop Journal, 45/4 (2004): 435-50. The Armenian experience has, of course, received attention in the context of the Armenian genocide, but there have been few efforts to address the experience of Armenian Christians in the context of the Arab provinces of the Ottoman Empire or in the colonial or post-colonial Arab world.

48 One new effort at just such a comparative approach is H. Sharkey (ed.), Unexpected Consequences: Christian Missionary Encounters and Cultural 'Conversions' in the Middle East, Africa, and Asia (forthcoming).

49 See N. Stene, 'The Challenge of the Diaspora as Reflected in a Coptic Sunday School', Journal of Eastern Christian Studies, 54 (2002): 77-90, and 'Into the Land of Immigration', in K. Vogt and N. van Doorn-Harder (ed.), Between Desert and City: The Coptic Orthodox Church Today (Oslo: Novus Vorlag, 1997); also G. Botros, 'Religious Identity as an Historical Narrative: Coptic Orthodox Immigrant Churches and the Representation of History', Journal of Historical Sociology, 19 (2006): 180.

\section{Bibliography}

Akasoy, A., 'Convicencia and its Discontents', International Journal of Middle East Studies, 42/3 (August 2010): 48999.

Antonius, G., The Arab Awakening: The Story of the Arab National Movement (London: Hamilton, 1938).

Armanios, F., 'The "Virtuous Woman": Images of Gender in Modern Coptic Society', Middle Eastern Studies, 38/1 (2002): 110-30.

Ateek, N., Faith and the Intifada: Palestinian Christian Voices (Maryknoll, NY: Orbis, 1992). 
Ateek, N., Justice, and Only Justice: A Palestinian Theology of Liberation (Maryknoll, NY: Orbis, 1989).

Betts, R. B., Christians in the Arab East: A Political Study (Athens: Lycabettus Press, 1975).

Botros, G., 'Religious Identity as an Historical Narrative: Coptic Orthodox Immigrant Churches and the Representation of History', Journal of Historical Sociology, 19 (2006): 174-201.

Cannell, F. (ed.), The Anthropology of Christianity (Durham: Duke University Press, 2006).

Chatelard, G., Briser la mosaique: Lien social et identities collective chez les chretiens de Madaba, Jordanie, 1870-1997 (Paris: Editions du CNRS, 2004).

Comaroff, J., and Comaroff, J., Of Revelation and Revolution, 2 vols. (Chicago: University of Chicago Press, 1991 and 1997).

Cooper, B., Evangelical Christians in the Muslim Sahel (Bloomington: Indiana University Press, 2006).

Cragg, K., The Arab Christian: A History in the Middle East (London: Mowbray, 1992).

Davis, E., 'A Sectarian Middle East?', International Journal of Middle East Studies, 40/4 (2008): 555-8.

van Doorn-Harder, N., Contemporary Coptic Nuns (Columbia: University of South Carolina Press, 1995).

van Doorn-Harder, N., 'Finding a Platform: Studying the Copts in the 19th and 20th Centuries', International Journal of Middle East Studies, 42/3 (2010): 479-82.

van Doorn-Harder, N., and Vogt, K. (eds.), Between Desert and City: The Coptic Orthodox Church Today (Oslo: Novus Vorlag, 1997).

El-Assal, R. A., Caught in Between: The Story of an Arab Palestinian Christian Israeli (London: SPCK, 1999).

Farah, N. K., A Continent Called Palestine: One Woman's Story (London: SPCK, 1996).

Fargues, P., 'Demographic Islamization: Non-Muslims in Muslim Countries', SAIS Review, 21/2 (2001): 103-16.

Firro, K., Metamorphosis of the Nation (al-Umma): The Rise of Arabism and Minorities in Syria and Lebanon, 1850-1940 (Brighton: Sussex Academic Press, 2009).

Fleischmann, E., 'Impact of American Protestant Missions in Lebanon on the Construction of Female Identity', Islam and Christian-Muslim Relations, 13/4 (2002): 411-26.

Haddad, R., Syrian Christians in Muslim Society: An Interpretation (Princeton: Princeton University Press, 1970).

Haddad, S., 'A Survey of Maronite Christian Socio-Political Attitudes in Postwar Lebanon', Islam and ChristianMuslim Relations, 12/4 (2001): 465-80.

Hagopian, E., 'Maronite Hegemony to Maronite Militancy: The Creation and Disintegration of Lebanon', Third World Quarterly, 11/4 (1989): 101-17.

Haiduc-Dale, N., Nationalism and Religious Identification: Palestinian Christians, 1918-1948, Ph.D. diss. (New York: New York University, 2009).

Hasan, S. S., Christians versus Muslims in Modern Egypt: The Century-Long Struggle for Coptic Equality (Oxford: Oxford University Press, 2003).

Henley, A., 'Politics of a Church at War: Maronite Catholicism in the Lebanese Civil War', Mediterranean Politics, 13/3 (2008): 353-69.

Heyberger, B., 'Eastern Christians, Islam, and the West: A Connected History', International Journal of Middle East Studies, 42/3 (2010): 475-8.

Hourani, A., Arabic Thought in the Liberal Age, 1798 - 1939 (London: Oxford University Press, 1962).

Huntington, S., The Clash of Civilizations and the Remaking of World Order (New York: Simon \& Schuster, 1996).

Huntington, S., 'The Clash of Civilizations?', Foreign Affairs, 72/3 (1993): 22-49.

Ibrahim, V., The Copts of Egypt: The Challenges of Modernisation and Identity (London: Tauris, 2010).

Jenkins, P., The Next Christendom: The Coming of Global Christianity (Oxford: Oxford University Press, 2002).

Joseph, S., 'Sectarianism as Imagined Sociological Concept and as Imagined. Social Formation', International Journal of Middle East Studies, 40/4 (2008): 553-4.

Khater, A., Embracing the Divine: Passion, Politics and Gender in the Christian Middle East, 1720-1798 (Syracuse: Syracuse University Press, 2011).

Lewis, B., 'The Roots of Muslim Rage', The Atlantic Monthly, 266/3 (September 1990): 47-60.

Lewis, B., What Went Wrong? The Clash between Islam and Modernity in the Middle East (New York: Oxford University Press, 2002).

Makari, P., Conflict and Cooperation: Christian-Muslim Relations in Contemporary Egypt (Syracuse: Syracuse University Press, 2007).

Makdisi, U., Artillery of Heaven: American Missionaries and the Failed Conversion of the Middle East (Ithaca: Cornell University Press, 2008).

Makdisi, U., 'Moving Beyond Orientalist Fantasy, Sectarian Polemic and Nationalist Denial', International Journal of Middle East Studies, 40/4 (2008): 559-60.

Maktabi, R., 'The Lebanese Census of 1932 Revisited: Who Are the Lebanese?', British Journal of Middle East Studies, 26/2 (1999): 219-41.

Masters, B., Christians and Jews in the Ottoman Arab World: the Roots of Sectarianism (Cambridge: Cambridge University Press, 2001).

McCallum, F., 'Christians in the Middle East: A New Subfield?' International Journal of Middle East Studies, $42 / 3$ (2010): 486-8. 
McCallum, F., 'The Political Role of the Patriarch in the Contemporary Middle East', Middle Eastern Studies, $43 / 6$ (2007): 923-40.

O'Mahony, A., 'The Chaldean Catholic Church: The Politics of Church-State Relations in Modern Iraq', Heythrop Journal, 45/4 (2004): 435-50.

O’Mahony, A., Gunner, G., and Hintlian, K. (eds.), The Christian Heritage in the Holy Land (London: Scorpion Cavendish, 1995).

Peteet, J., 'How Useful Has the Concept of Sectarianism Been for Understanding the History, Society, and Politics of the Middle East?', International Journal of Middle East Studies, $40 / 4$ (2008): 550-2.

Porter, A., Religion Versus Empire? British Protestant Missionaries and Overseas Expansion, 1700-1914 (Manchester: Manchester University Press, 2004).

Raheb, M., I Am a Palestinian Christian (Minneapolis: Fortress Press, 1995);

Robson, L., Colonialism and Christianity in Mandate Palestine (Austin: University of Texas Press, 2011).

Robson, L., 'Palestinian Liberation Theology, Muslim-Christian Relations and the Arab-Israeli Conflict', Islam and Christian-Muslim Relations, 21/1 (2010): 39-50.

Roussos, S., 'The Greek Orthodox Tradition: International Politics, Ethnicity and Theological Development in the Middle East', Bulletin of the Royal Institute for Inter-Faith Studies, 7/2 (2005): 141-57.

Roussos, S., 'The Patriarchate of Jerusalem in the Greek, Palestinian, Israeli Triangle', One in Christ, 39/3 (2004): 15-25.

Rowe, P., 'The Challenge of Political Islam: Non-Muslims and the Egyptian State', Middle East Journal, 64/4 (2010): 654-5.

Rowe, P., 'The Middle Eastern Christian as Agent', International Journal of Middle East Studies, 42/3 (2010): 472-4.

Sabella, B., 'The Emigration of Christian Arabs: Dimensions and Causes of the Phenomenon', in A. Pacini (ed.), Christian Communities in the Arab Middle East: The Challenge of the Future (Oxford: Clarendon Press, 1998), $127-54$.

Sabella, B., 'Palestinian Christian Emigration from the Holy Land', Proche-Orient Chretien, 41 (1991): 74-85.

Sanneh, L., The Changing Face of Christianity: Africa, the West, and the World (Oxford: Oxford University Press, 2005).

Sanneh, L., Disciples of All Nations: Pillars of World Christianity (Oxford: Oxford University Press, 2008).

Sedra, P., 'John Lieder and his Mission in Egypt: The Evangelical Ethos at Work among Nineteenth-Century Copts', Journal of Religious History, 28/3 (2004): 219-39.

Sedra, P., 'Missionaries, Peasants, and the Protection Problem: Negotiating Coptic Reform in Nineteenth-Century Egypt', in A. Amanat and M. T. Bernhardsson (eds.), U.S. - Middle East Historical Encounters: A Critical Study (Gainesville: University of Florida Press, 2007), 77-100.

Sedra, P., 'Writing the History of the Modern Copts: From Victims and Symbols to Actors', History Compass, 7/3 (2009): 1049-63.

Sharkey, H., American Evangelicals in Egypt: Missionary Encounters in an Age of Empire (Princeton: Princeton University Press, 2008).

Sharkey, H. (ed.), Unexpected Consequences: Christian Missionary Encounters and Cultural 'Conversions' in the Middle East, Africa, and Asia (forthcoming).

Shatzmiller, M. (ed.), Nationalism and Minority Identities in Islamic Societies (Montreal: McGill-Queen's University Press, 2005).

Shenoda, M., 'Displacing Dhimmi, Maintaining Hope: Unthinkable Coptic Representations of Fatimid Egypt', International Journal of Middle East Studies, 39/4 (2007): 587-606.

Stene, N., 'The Challenge of the Diaspora as Reflected in a Coptic Sunday School', Journal of Eastern Christian Studies, 54 (2002): 77-90.

Stene, N., 'Into the Land of Immigration', in K. Vogt and N. van Doorn-Harder (eds.), Between Desert and City: The Coptic Orthodox Church Today (Oslo: Novus Vorlag, 1997), 254-64.

Strickert, F., 'Christianity in the Gulf', Washington Report on Middle East Affairs 19/2 (March 2000): 68-71.

Tadros, M., 'Vicissitudes in the Entente between the Coptic Orthodox Church and the State in Egypt (19522007)', International Journal of Middle East Studies, 41/2 (2009): 269-87.

Visawanathan, G., Outside the Fold: Conversion, Modernity, and Belief (Princeton: Princeton University Press, 1998).

Voile, B., Les Coptes d'Egypte Sous Nasser: Saintete, Miracles, Apparitions (Paris: CNRS, 2004).

Walls, A., The Missionary Movement in Christian History: Studies in the Transmission of Faith (Maryknoll, New York: Orbis, 1996).

Watenpaugh, K., Becoming Modern in the Middle East: Revolution, Nationalism, Colonialism, and the Arab Middle Class (Princeton: Princeton University Press, 2006).

White, B., 'The Nation-State Form and the Emergence of 'Minorities' in French Mandate Syria, 1919-1939', Ph.D. diss. (Oxford: Oxford University, 2008).

Wilken, R. L., The Land Called Holy: Palestine in Christian History and Thought (New Haven: Yale University Press, 1992).

Ye'or, B., The Decline of Eastern Christianity under Islam: from Jihad to Dhimmitude (Madison, NJ: Fairleigh Dickinson University Press, 1996).

Ye'or, B., The Dhimmi: Jews and Christians under Islam (Rutherford, NJ: Fairleigh Dickinson University Press, 1985). Zubaida, S., 'Islam and Secularization', Asian Journal of Social Science, 33/3 (2005): 438-48. 